way to our disengagement from South Vietnam." One must understand that negotiation is war in another form, where both are limited attempts to alter an adversary's hopes and expectations.

Thayer, however, soars above the moves and countermoves of war and diplomacy. Total war (and deterrence) and total peace are his twin , aspirations. This is no new thought; alternating between the two is the very essence of the American attitude toward war and peace. Thayer simply wants the two organized in one system of massive, unreformable counter-society deterrence. "One must have the stomach for selective terror," says the revoutionary warrior. "One must have the stomach for total terror," says Thayer the pacifist warrior.

If he is serious, he should espouse Brennan's ironic "thought-experiment." He ought to espouse the mutual adversarial mining of all the world's major cities. By that scheme -less costly, more workable than the present deterrent-a MAD policy could insure that no nation can be lor would want to be the adversary of another. The lion will lie down with the lamb, and there will be peace on earth among all resolute men of ill will.

I do not believe that peace and justice can be erected over such a moral abyss.

\section{The Colonels and Their Critics}

To the Editors: First of all, let me say that I have long admired Worldview, CRIA, and all they stand for....

All the greater was my shock to find in the May, 1972, issue a piece which can only be characterized as utterly amoral. I refer to the article by David Holden on Greece ("The Greek Colonels and Their Critics"). Everybody is entitled to his opinion.
But there is a difference between presenting one's frank opinion and distorting and slanting facts in order to make a case. This is what this author does. I must say that what he said sounded depressingly familiar. I had a feeling of déjd vu or, rather, déjd entendu. Yes, I said to myself, this is exactly what I read about the Nazis and their deeds in the thirties by those outside Germany intent on whitewashing the regime and playing down its misdeeds. The same argument that it was the preceding parliamentary regime that had discredited itself and thus was responsible for the rise of the dictatorship (as if that was a valid excuse for what the dictatorship does and stands for!). The same playing down of "atrocities," which the author partly does not admit ("allegations of torture," "circumstantial reports of deliberate torture") and partly calls "exaggerated, if not fabricated." The very term "atrocity stories" was invented by Goebbels ("Greuelmärch$e n ")$. It's all a deliberate "antitorture campaign" by Communists and other leftists hostile to the colonels (such as, apparently, all the member-states of the Council of Europe that expelled the regime!). Yes, indeed, one political prisoner, after release, regained his health, which proves that things cannot be all that bad; yes, indeed, "that classical form of punishment known as the falanja-striking the soles of the feet with a bar"-is the only kind of maltreatment specifically mentioned (for what really happens, see the book review on p. 54 of the same issue of Worldview). The concluding argument is the old and hoary one of "national character"-the Greeks were always-like that. The colonels emerge as sort of buffoons, who engage in sometimes ridiculous antics, such as prohibiting long hair or miniskirts-thus trying to create the impression that this was the worst they do (exactly as in the case of the Nazis, whose revival of certain Teutonic customs and antics was emphasized by their "critics").

It is beyond my understanding how such a piece of whitewash of, and apology for, a despicable regime could be accepted by your publication. There are no moral considerations in it. There is no discussion, or even mention, of the ethical problems involved. There is not even "realism" (Christian or otherwise). One expects this kind of essay in a Joe McCarthyite or Wallaceite or Agnewite publication, but not in Worldview. The least you can do is to either publish a piece that deals with the Greek dictatorship under some viewpoints of "ethics and politics" or discuss it editorially, and by distancing yourselves from its tenor. John H. Herz

Department of Political Science

City College

New York, N.Y.

David Holden Responds:

It just goes to show, doesn't it, how hard it is to write dispassionately about Greece, of all places, without rousing an excess of passion in one's readers. As that was one of the points I was making in my book, from which the article was adopted, I must thank Mr. Herz for so intemperately confirming at least a litthe of my diagnosis.

$\mathrm{He}$ is, of course, entitled to his views about my "utter amorality," but frankly it escapes me how anyone whose mind was not previously clouded by a surfeit of moral indignation could see what I wrote as a "whitewash"-still less some diabolic imitation of Dr. Coebbels. Since Mr. Herz has managed to see it that way, however, may I suggest that he now examine some of his own assumptions? E.g., that there is a specific set of moral/ethical absolutes which should govern our interpretation of politics the world over (Vietnam? The Arab-Israel conflict? Ulster? Whose absolutes?) and, by extension, that these may be used by Worldview to exclude material that does not correspond with them. Is this what he teaches at his Department of Political Science? I hope not-if only to save the name of science from abusel 